\title{
China and BEPS
}

\author{
Reuven Avi-Yonah ${ }^{1, *}$ and Haiyan $\mathrm{Xu}{ }^{1,2}$ \\ 1 Law School, the University of Michigan, 625 South State Street, Ann Arbor, MI 48109-1215, USA \\ 2 Law School University of International Business and Economics, Beijing 100029, China; haixu@umich.edu \\ * Correspondence: aviyonah@umich.edu
}

Received: 15 November 2017; Accepted: 16 January 2018; Published: 24 January 2018

\begin{abstract}
This article provides an overview of China's reaction to the G20/OECD Base Erosion and Profit Shifting (BEPS) project. From 2013 to 2015, the OECD developed a series of actions designed to address BEPS activities by multinational enterprises, culminating in a final report of 15 action steps. The article reviews and explains China's reaction to the BEPS project and its actions in detail, with a particular focus on transfer pricing issues. It shows that China has actively participated in both developing and implementing the BEPS project. The article further suggests that in the post-BEPS era, China is expected to implement the BEPS project in a more consistent and coherent way, and will take whatever measures necessary to guarantee the successful implementation of the BEPS package in collaboration with the global community.
\end{abstract}

Keywords: BEPS; China

\section{Introduction}

Following the financial crisis of 2008 and ensuing austerity, the OECD and G20 launched the Base Erosion and Profit Shifting (BEPS) project in 2013. The BEPS project culminated in October, 2015 with the release of a series of action steps that the OECD and G20 countries have undertaken to adopt. ${ }^{1}$ OECD Secretary-General Angel Gurria has stated that "Base erosion and profit shifting affects all countries, not only economically, but also as a matter of trust. BEPS is depriving countries of precious resources to jump-start growth, tackle the effects of the global economic crisis and create more and better opportunities for all. However beyond this, BEPS has been also eroding the trust of citizens in the fairness of tax systems worldwide. The measures we are presenting today represent the most fundamental changes to international tax rules in almost a century: They will put an end to double non-taxation, facilitate a better alignment of taxation with economic activity and value creation, and when fully implemented, these measures will render BEPS-inspired tax planning structures ineffective" (OECD 2015).

China has actively participated in both developing and implementing the BEPS project. China's tax base has been seriously eroded by aggressive international tax planning that has the effect of artificially shifting profits to locations where they are subject to non-taxation or substantially reduced taxation.

In the first three earlier decades since the late 1970s, China had received more inbound foreign direct investments including advanced technologies and intangibles than the outbound investment of Chinese investors. However, as China started to implement the "Going-out" strategy in the 21st century, in particular the initiative of "one belt and one road" (OBOR), more and more China-based corporations are increasingly active in outbound investment and intangibles export oversea. In response to the new scenario of increasingly accelerated globalization of China-based MNE groups, China has to

1 On BEPS see, e.g., (Ault 2013; Dharmapala 2014a, 2014b; Brauner 2014; Ault et al. 2014; Vann 2014; Shaviro; Rosenzweig 2014; Grinberg 2015). 
take a very holistic approach to deal with the BEPS challenges from different perspectives, including domestic action items (items 2-5), treaty-based action items (items 6-7) and transfer pricing measures (items $8-10$ and 13).

In the post-BEPS era, China is expected to implement the BEPS project in a more consistent and coherent way, and will take whatever measures necessary to guarantee the successful implementation of the BEPS package in collaboration with the global community. That is why the SAT has quickly translated many minimum standards and recommendations of BESP project into domestic regulations.

The following sections describe China's involvement in the BEPS project in detail, with particular emphasis on transfer pricing. They explain why China needs to continue to implement the BEPS action steps and what problems might be anticipated as it does so.

\section{Overview of China's Involvement in the BEPS Project}

\subsection{China as a Victim of BEPS}

Although China is the second largest economy, the largest trader of goods, the top thirf country of outbound direct investment in the world (Ministry of Foreign Affairs of the People's Republic of China 2016), and the top third country of the inbound direct investment ${ }^{2}$, China is one of the major victims of BEPS. In the past four decades of market-oriented reform since the late 1970s, China's tax base has been seriously eroded by aggressive international tax planning that has the effect of artificially shifting profits to locations where they are subject to non-taxation or reduced taxation.

In response to Subcommittee on Base Erosion and Profit Shifting Issues for Developing Countries of UN Committee of Experts on International Cooperation in Tax Matters, China clearly indicated, "China currently does not have a system which quantitatively analyzes the base erosion in our country. Yet, we do find, and it is obvious, that the major threat China faces is that many MNE groups have shifted their profits by means of tax planning and transfer pricing" (UN n.d.).

Without any exaggeration, almost all the highly speculative tax evasion and avoidance strategies and tactics have been widely used by MNEs doing business in China, including but not confined to hybrid mismatch arrangements, controlled-foreign-company (CFC), interest deductions, harmful tax practices, treaty shopping, artificial avoidance of permanent establishment (PE) status, manipulative transfer pricing, etc.

In particular, China has identified some most common BEPS practices and structures as the followings. First, MNE groups tend to adopt transfer pricing principles and methodologies in such intra-group dealings as purchase and sale transactions, financing transactions, equity transfer transactions and service provision transactions, in order to lower the profits of their subsidiaries in China. Second, MNE groups establish shell companies with no genuine economic substances in the low-tax jurisdictions and tax heavens to shift profits. As responses to the above mentioned BEPS concerns, China has enacted the general anti-avoidance rules and carry out TP audits to recover the taxes (UN n.d.).

Chinese tax authorities makes their judgment by auditing MNE groups' annual filing and reviewing their contemporaneous documentation, considering the profit levels of the industry and comparable companies, and performing functional analysis. They then make adjustments as necessary when their judgment is made. However, China has encountered two primary obstacles in assessing whether the appropriate amount of profit is reported in China and in ensuring that tax is paid on such profit. First, China is in lack of comparable companies. China's domestic legislation requires that the listed companies must make mandatory disclosures, but the unlisted companies are not required to make such disclosures. Therefore, it is unrealistic to find comparables from the over

2 China has retained its top-three ranking in the 2017 edition of A.T. Kearney's Foreign Direct Investment Confidence Index as investors turn more optimistic about its economic prospects (China Daily 2017). 
2000 listed companies in China. Second, some corporate taxpayers are often unwilling to provide the tax authorities with necessary information, such as resale prices, especially the business operation and profits throughout the supply chain. Their reluctance to cooperate increases the difficulties for the tax authorities to have a big picture in mind in their audits. ${ }^{3}$

As far as the most important BEPS action is concerned, China believes that TP-related actions are most important to it. China also considers BEPS Action 11 increasingly important, as China is dedicated to establish methodologies to collect and analyze data on BEPS, which is something developing countries should work hard on. ${ }^{4}$

To warrant sustainable growth and development, China has good reasons to share the priorities identified by OECD/G20 BEPS package, and to take a stronger and more coordinated stance in fighting against the excessive BEPS opportunist behaviors of MNEs that seek to avoid paying their fair share of taxes. Generally speaking, China has prioritized its efforts on the implementation of BEPS project in various aspects in the past years.

\subsection{Active Participation in the Development of BEPS Project}

China has been active in shaping the process of developing the BEPS package not only by and through the platform OCED/G20, but also by and through the UN Committee of Experts on International Cooperation in Tax Matters (the UN Tax Committee). As a subsidiary body of the Economic and Social Council, the UN Tax Committee is responsible for keeping under review and update, as necessary, the UN Model Double Taxation Convention between Developed and Developing Countries and the Manual for the Negotiation of Bilateral Tax Treaties between Developed and Developing Countries, and providing a framework for dialogue with a view to enhancing and promoting international tax cooperation among national tax authorities and assesses how new and emerging issues could affect this cooperation (Financing for Development n.d.). The current member from China is Ms. Xiaoyue Wang, the Director for Anti-avoidance Division, International Taxation Department, State Administration of Taxation (SAT) (Economic and Social Council 2014). The Subcommittee on Base Erosion and Profit Shifting Issues for Developing Countries was established at the ninth session of the UN Tax Committee in October 2013, aiming at communicating with officials in developing countries and ensure their views are fed into both the OECD/G20 BEPS project as well as the on-going United Nations tax cooperation work (Committee of Experts on International 2014). China has been closely working together with other countries in advancing the progress of the BEPS project, including but not confined to making submission to the Subcommittee questionnaire on how developing countries view and prioritize the BEPS project issues in 2014.

Although not a member of the OECD, China has been the key partner of the OECD since $2007 .{ }^{5}$ A Key Partner of the OECD plus a member of G20, China has contributed actively to the development of BEPS package. As Angel Gurría, the OECD Secretary-General indicated, China's unique perspectives and policy experience have enriched the work of the OECD, increased the relevance of our analyses and supported a more inclusive global policy debate in today's challenging global economic environment. Looking ahead, even stronger engagement of China with the OECD would help increase recognition of the country's reform progress and strengthen its role in global economic governance (OECD 2016a).

In 2013, Chinese President Xi Jinping attended the G20 Summit of St. Petersburg, and declared that, "China supports strengthening of multilateral collaboration on tackling tax avoidance, and is willing to make its contribution to the improvement of international tax governance mechanism" on

3 See China's reply to the BEPS Questionnaire of the UN Subcommittee, available at www.un.org/esa/ffd/wp-content/ uploads/2014/10/ta-BEPS-CommentsChina.pdf.

4 See China's reply to the BEPS Questionnaire of the UN Subcommittee, available at www.un.org/esa/ffd/wp-content/ uploads /2014/10/ta-BEPS-CommentsChina.pdf.

5 In May 2007, the Council, meeting at ministerial level, invited the Secretariat to strengthen OECD cooperation with Brazil, India, Indonesia, the People's Republic of China and South Africa through "Enhanced Engagement" programs. These Key Partners contribute to the OECD's work in a sustained and comprehensive manner (OECD n.d.). 
the first session of the Eighth Summit of G20 leaders" (Ministry of Foreign Affairs of the People's Republic of China 2013). G20 Leaders' Declaration of September 6, 2013 acknowledged the urgency to address BEPS, tackle tax avoidance, and promote tax transparency and automatic exchange of information. In order to minimize BEPS, we call on member countries to examine how our own domestic laws contribute to BEPS and to ensure that international and our own tax rules do not allow or encourage multinational enterprises to reduce overall taxes paid by artificially shifting profits to low-tax jurisdictions. We acknowledge that effective taxation of mobile income is one of the key challenges (G20 Information Centre 2013).

In 2014, President Xi Jinping attended the G20 Summit of Brisbane, and further supported the development of BEPS package. G20 Leaders' Communiqué of 16 November 2014 declared, "Profits should be taxed where economic activities deriving the profits are performed and where value is created. We welcome the significant progress on the G20/OECD BEPS Action Plan to modernize international tax rules. We are committed to finalizing this work in 2015, including transparency of taxpayer-specific rulings found to constitute harmful tax practices. We welcome progress being made on taxation of patent boxes (G20 Information Centre 2014)".

Quickly following the publication of the BEPS package by OECD on 5 October 2015, SAT released the Chinese version of the BEPS package on its official website on 10 October 2015 (State Administration of Taxation 2015a). The translation of BEPS package is very helpful for the research and application of the BEPS packages in China.

In November 2015, President Xi Jinping attended the G20 Summit of Antalya, and co-adopted G20 Leaders' Communiqué of 16 November 2015, which endorsed the package of measures developed under the ambitious G20/OECD BEPS project. The Communiqué stated that, "We, therefore, strongly urge the timely implementation of the project and encourage all countries and jurisdictions, including developing ones, to participate. To monitor the implementation of the BEPS project globally, we call on the OECD to develop an inclusive framework by early 2016 with the involvement of interested non-G20 countries and jurisdictions which commit to implement the BEPS project, including developing economies, on an equal footing (G20 Information Centre 2015)."

To be well prepared for the involvement at the level of OECD discussion on BEPS, the SAT set up both Leadership Group and Working Group on the G20 Tax Reform Project, and clarified the duties and working plans these two groups. More than 50 officials have deeply participated in the conferences, research activities and advice feedbacks on all relevant topics of BEPS project. The SAT also appointed its representative to the Steering Committee of the BEPS, working with other committee members on designing, supervising and reviewing the proposed BEPS actions. From 2013 through 2015, the SAT has participated 86 meetings relevant to the BEPS project, and submitted over 1000 pieces of position statements and proposals to the OECD. Many of the proposals have been adopted and reflected in the final BEPS package. China has made significant contributions to the recognition of core principles of the BEPS package and the successful completion of the BEPS project, and also effectively advocated for the developing countries and emerging economies (State Administration of Taxation 2015a).

On 11 May 2016, China hosted the 10th Forum on Tax Administration in Beijing, and attracted the Heads of 44 tax administrations in different jurisdictions. The Forum addressed the coordinated action required for the effective implementation of the G20/OECD international tax agenda, as well as the challenges related to building modern tax administrations. Wang Jun, the Commissioner of SAT, and Pascal Saint-Amans, the Director of OECD Centre for Tax Policy and Administration, attended the Forum.

In June 2016, the Inclusive Framework to Implement BEPS was established to allow OECD Member and Partner countries to discuss the BEPS issues on an equal footing. As an active member of the steering group and as the deputy chair for the Inclusive Framework, China is expected to play an important role in helping define and implement international tax policies.

In September 2016, China hosted the G20 Summit of Hangzhou. The close collaboration throughout China's G20 Presidency in 2016 brought the role of China in implementing the BEPS project to a new 
level. BEPS project was a highlighted priority in G20 Leaders' Communiqué of 4-5 September 2016. "We will continue our support for international tax cooperation to achieve a globally fair and modern international tax system and to foster growth, including advancing on-going cooperation on BEPS, exchange of tax information, tax capacity-building of developing countries and tax policies to promote growth and tax certainty. We welcome the establishment of the G20/OECD Inclusive Framework on BEPS, and its first meeting in Kyoto"; "China would make its own contribution by establishing an international tax policy research center for international tax policy design and research". 6

In 2016, the OECD and the SAT jointly established a Multilateral Tax Centre in Yangzhou, the first tax center in a non-member country. The Centre, integrated into the OECD Network of MTCs, will continue to support a consistent implementation of BEPS outcomes for the benefit of developing countries.

To reflect and accommodate reasonable claims and suggestions from the local tax authorities, business community and the civil society, SAT communicates with the interested organizations and individuals on a regular basis. In addition to promoting the mutual understanding between the BEPS Working Group and the local tax authorities responsible for international tax law enforcement, the SAT has paid great attention to the opinions from the MNEs, domestic firms, accounting firms, tax consulting firms and universities. For instance, representatives from KPMG, PWC, EY, Deloitte Touche Tohmatsu Limited, Baker McKenzie, Microsoft (China), JD.Com Inc., Lenovo Group Ltd., Central University of Finance \& Economy and Xiamen University were invited to participate the workshops on BEPS of 8 June of 2015 sponsored by the SAT. Zhang Zhiyong, the Deputy Commission of the SAT acknowledged the significance of the efficient communication channels between SAT and stakeholders (State Administration of Taxation 2015b).

The dialogues and interactions between the government and the private sector has enabled SAT to have a clear picture of the different concerns and expectations of taxpayers, consulting firms, and independent third parties for the purpose of making informed and feasible on shaping and implementing the BEPS project. Needless to say, the technical details of the BEPS package and the domestic rules and mechanism are also easy to be understood by the taxpayers and the professionals. The informed academia is also able to advise the government in choosing better policy alternatives in case of controversy.

China's active participation in the formulation of the BEPS package naturally leads to its efficient translation of BEPS package into domestic rules. In addition to successfully introducing some of its best practices into the BEPS package, China has opportunities to understand the positions and rationales of other jurisdictions. Thus, potential misunderstandings could be minimized in the process of bilateral or multilateral collaboration on implementation of the BEPS package.

\subsection{Chinese Legal Framework Of Corporate Income Tax as it Relates to BEPS Implementation}

The Income Tax Law for Enterprises with Foreign Investment and Foreign Enterprises (ITLEFIFE) of 9 April 1991 created many measures providing tax relief for the purpose of boosting foreign investment. For instance, under Article 8 (1) of ITLEFIFE, any manufacturing enterprise with foreign investment scheduled to operate for a period of not less than ten years shall, from the year beginning to be profitable, be exempted from income tax in the first and second years and allowed a 50\% reduction in the third through fifth years. However, the income tax exemption or reduction for enterprises with foreign investment engaged in the exploitation of resources such as petroleum, natural gas, rare metals, and precious metals shall be regulated separately by the State Council. Enterprises with foreign investment which actually operate for a period less than ten years, shall repay the amount of income tax exempted or reduced.

Although there are no exact statistics on the use of these provisions and their effectiveness, many foreign-funded enterprises and foreign enterprises benefited a lot from the tax holidays offered

6 G20 Leaders' Communique Hangzhou Summit, 4-5 September 2016 (G20 2016). 
by the ITLEFIFE. However, most of the tax reliefs offered to the enterprises with foreign investment and foreign enterprises, were not available to Chines domestic firms that were governed by the Interim Regulation on Corporate Income Tax promulgated by the State Council on 13 December 1993. The double tax standards and the tax reliefs only available to foreign firms were criticized by many domestic firms, especially private firms as discrimination against domestic firms. Theoretically speaking, the double tax standards were incompatible with the national treatments and fair competition requirements of globalized market economy. Therefore, it is necessary to terminate the double tax relief standards for domestic firms and foreign firms after China joined WTO in 2001.

The Corporate Income Tax Law (CITL), applicable to both domestic and foreign firms, was promulgated on 16 March 2007, and came into force as of 1 January 2008. The ITLEFIFE was repealed simultaneously as of 1 January 2008. To ensure smooth transitional period, Article 57 of the CITL declares, for the enterprises that were established prior to the promulgation of the CITL and enjoyed lower tax rates according to the provisions of the previous tax laws and administrative regulations, their income tax rates shall, according to the provisions of the State Council, be gradually transferred to the tax rate provided in the CITL within five years after the CITL is promulgated. The enterprises that have enjoyed the preferential treatment of tax exemption for a fixed term may, according to the provisions of the State Council, continue to enjoy such treatment after the promulgation of the CITL until the fixed term expires.

However, for those that have failed to enjoy the preferential treatment due to failure to make profits, the term of preferential treatment may be counted as of the year when the CITL is promulgated. The high- and new-tech enterprises that need the key support of the state newly established in the particular areas established by law for developing foreign economic cooperation and technological exchanges or in the areas where the State Council has provided for the implementation of the above mentioned special policies may continue to enjoy transitional preferential tax treatments, according to the specific measures to be formulated by the State Council. Other enterprises falling in the encouraged category as already determined by the State Council may enjoy the preferential treatment of tax reduction or exemption according to the provisions of the State Council.

Therefore, the implementation of BEPS package in China has to be conducted in the context of Chines tax legal system based on the CITL and its subordinated regulations and guidances.

\subsection{Taxpayers Rights and BEPS Implementation}

All categories of taxpayers, including individuals, investors, small businesses, large businesses, tax-exempt organizations are most likely to be affected by the implementation of BEPS in different ways. For instance, the domestic firms might be able to acquire a level playing field to compete with the multinationals, as the multinational competitors will be forced to give up their over-speculative BEPS strategies as a comparative competitive advantage. Of course, the corporate taxpayers active in global trade and investment will be affected most among the taxpayers. Anyway, the traditional race to the bottom are expected be reversed to some extent in terms of international tax planning.

Taxpayers in China enjoy a series of rights under the Law on the Administration of Tax Collection (LATC) of 2015. Article 8 of the LATC says, "Taxpayers and withholding agents shall have the right to inquire of the tax authorities about the tax laws and administrative regulations of the State as well as the information related to tax payment procedures. Taxpayers and withholding agents shall have the right to require the tax authorities to maintain confidentiality for the information of the taxpayers and withholding agents. The tax authorities shall maintain confidentiality for the information of the taxpayers and withholding agents in accordance with the law. Taxpayers shall, in accordance with the law, have the rights to apply for the reduction, exemption and refund of tax. Taxpayers and withholding agents shall have the right to statement and the right of defense to the decisions made by tax authorities; and shall have the rights to apply for administrative reconsideration, institute administrative litigation, ask for State compensation, etc. in accordance with the law. Taxpayers and 
withholding agents shall have the right to bring charges against or make exposure of any tax authority or tax official for violation of laws or disciplines".

The taxpayers' rights are closely relevant to the implementation of BEPS in China, as the implementation of BEPS in China must be based on the rule of law, which is clearly recognized by Chinese Constitution and legal framework. This means that domestic tax statutes or regulations need to be reformed to reflect the outcomes of BEPS package, and that the anti-BEPS rules will be enforced in a transparent and fair way.

The taxpayers' rights may influence with BEPS-related reforms in various ways. First, the taxpayers may propose the legislative or regulatory advice in the process of legal reform. According to Article 5 of Legislation Law of 2015, legislation shall represent the will of the people, carry forward socialist democracy, and in adherence to openness in legislation, ensure the people's participation in legislative activities through various channels. Second, the taxpayers may claim their rights, including the right to information, the right of fair treatment and the right to judicial remedy if they disagree with the tax authorities on certain BEPS issues.

If the taxpayers are unsatisfied with the administrative decisions of the tax authorities in China, they are entitled to take legal actions to the courts of justice. Although the cross-border tax litigations were not so active as the international commercial disputes in the past years, the judicial remedy will be available to the corporate taxpayers including the MNEs unsatisfied with the special tax adjustment made by Chinese tax authorities.

\section{Rigorous Responses to Mainly Domestic BEPS Action Items (Items 2-5)}

\subsection{Brief Introduction}

The enactment of the CITL of 2007 and the abolishment of the ITLEFIFE of 1991 were identifiably already compatible with the purpose of the BEPS project, in particular, the single tax principle. The rules on special adjustments to tax payments in Chapter VI of the CITL are particularly compatible with the BEPS project.

China has also made numerous BEPS-related rule changes after and even before the publication of the BEPS package. The SAT has issued a series of regulations or guidances to implement BEPS, including but not confined to the General Anti-Avoidance Rule (GAAR), the Offshore Indirect Transfers Circular of 2015, Beneficial Ownership Circulars and the Outbound Payment Notice (2015). The GAAR can be invoked to prevent arrangements or transactions that result in the abuse of tax preferences, the abuse of tax treaties, the abuse of corporate forms and tax avoidance using tax heavens, and other arrangements without reasonable business purposes.

\subsection{Responses to BEPS Action 2}

The BEPS Action 2 Report "Neutralizing the Effects of Hybrids Mismatch Arrangements" is designed to fix the loopholes associated with the hybrid mismatch arrangements. On 22 August 2016, OECD releases discussion draft on branch mismatch structures under BEPS Action 2 Report (OECD 2016b). This discussion draft applies the analysis and recommendations set out in the Action 2 Report to mismatches that can arise through the use of branch structures. The discussion draft identifies five basic types of branch mismatch arrangements and sets out preliminary recommendations for domestic rules, based on those in the Action 2 Report, which would neutralize the resulting mismatch in tax outcomes.

China has been trying its best to address certain hybrid mismatch arrangements, to implement and apply hybrid mismatch rules in accordance with policy objectives of BEPS Action 2 Report. As debt and equity are treated differently for income tax purposes under current tax system, it is important to properly characterize a hybrid instrument. In order to determine accurately the tax treatment of hybrid mismatch, Bulletin Regarding Corporate Income Tax Treatments for Companies Engaging in 
Hybrid Investments (SAT Bulletin 41 of 2013) was promulgated on 15 July 2013 by the SAT, pursuant to the CITL and its Implementation Regulations (CITLIR) (State Administration of Taxation 2013).

Hybrid investment is defined as a form of investment characterized by both equity and debt. The corporate income tax treatments stipulated in Bulletin 41 shall apply to hybrid investments meeting all of the following five conditions.

First, the recipient corporation of a hybrid investment ("target corporation") should make regular interest payments (including minimum interest, fixed profit or fixed dividends) as agreed in investment contract/agreement. This means that the investment return of the hybrid investment is not dependent on the financial performance of the target corporation.

Second, the hybrid investments should either have a clear term of investment or specific investment conditions, and the target corporation must redeem the investment or repay the principal upon the expiration of the term of investment or the satisfaction of specific investment conditions.

Third, the hybrid investor may not have the ownership of the net assets of the target corporation.

Fourth, the hybrid investor should not have the right to elect or to be elected on governing bodies of the target corporation, including the general meeting of shareholders, the board of directors or the board of supervisors. This means that the hybrid investor shall be neither qualified to vote on the appointment and dismissal of directors, supervisors and senior executives, nor qualified to be elected as directors, supervisors and senior executives.

Fifth, the hybrid investor may not participate in daily production and management of the target corporation.

In case of payment of the interest, the interest income received by the hybrid investor from the target corporation, shall be recognized and included in taxable income for corporate income tax purposes on the day when the interest payment becomes due, the interest expense incurred by the target corporation, shall be recognized on the day when the interest payment becomes due and deductible for corporate income tax purposes according to the CITL, CITLIR and Article 1 of SAT Bulletin Regarding Certain Issues Related to Corporate Income Tax (SAT Bulletin 34 of 2011). In case of redemption of the investments, the difference between redemption price and investment cost shall be recognized as debt restructuring gain upon redemption and separately included in taxable income of the current period for corporate income tax purposes.

SAT Bulletin 41 of 2013 took effect on 1 September 2013. For tax cases on hybrid investment already settled before its enforcement, no adjustments should be made, although the unsettled cases should be governed by SAT Bulletin 41 .

However, the SAT has not issued further special rules on hybrid mismatch arrangements after the release of the BEPS package in October 2015. According to the BEPS Action 2 Report, China is expected to undertake internal periodic review of the operation of hybrid mismatch rules as necessary to determine whether they are operating as intended, and make information about hybrid mismatch exchange procedures available to taxpayers. This author kindly recommends the SAT to comprehensively update its hybrid mismatch rules including those arising through the use of branch structures in the near future.

\subsection{Responses to BEPS Action 3}

According to the BEPS Action 3, it is a minimum standard for the countries to undergo periodic OECD monitoring of $C F C$ rules. Although Action 3 does not contain any rules or prescriptions relating to CFCs, this is an important item.

Article 45 of CITL provides for the general principles on identification of the CFCs by clarifying that, with regard to an enterprise that is established by a resident enterprise, controlled by a resident enterprise, or by a Chinese resident who is located in a country (region) where the actual tax burden is obviously lower than the tax rate as prescribed in paragraph 1 of Article 4 of this Law, if the profits are not distributed or are distributed partially for a cause that is not a reasonable business operation, 
the portion of the aforesaid profits attributable to this resident enterprise shall be included in its incomes of the current period.

Chapter VIII of the Measures for the Implementation of Special Tax Adjustments (for Trial Implementation) (Circular 2 of 2009) released by the SAT deals with the CFCs in details from Article 76 through Article 84. The CFC refers to a foreign enterprise which is formed in a country (or region) where the actual tax rate is lower than $50 \%$ of the tax rate set out in Article 4 (1) of the EITL and is controlled by a resident enterprise or by a resident enterprise and Chinese individual residents and whose profits are not distributed or are distributed in a reduced amount for reasons other than reasonable needs for business operation. ${ }^{7}$

The term "control" refers to a substantive control in terms of shares, capital, business operation, purchase and sales, etc. Control in shares means that a single Chinese resident shareholder directly holds or indirectly in a multilayered structure holds at least $10 \%$ of the voting shares of a foreign enterprise in any day of a taxable year, and the Chinese resident shareholders shall jointly hold at least $50 \%$ of the shares of the foreign enterprise. If the Chinese resident shareholders hold shares indirectly in a multilayered structure, their shareholding proportion shall be computed by multiplying the shareholding proportions at all layers. If the shareholding proportion in a middle layer exceeds $50 \%$, the proportion shall be treated as $100 \%$ in calculation. ${ }^{8}$

The taxation authority shall summarize and examine the information on overseas investment declared by a Chinese resident enterprise shareholder, and serve a Notice of Confirmation of a Chinese Resident Enterprise Shareholder of a Controlled Foreign Enterprise on the Chinese resident enterprise shareholder of the controlled foreign enterprise. If the Chinese resident enterprise shareholder meets the taxation conditions as prescribed in Article 45 of the CITL, the taxation authority shall levy tax on it according to the relevant provisions. ${ }^{9}$

If the Chinese resident enterprise shareholder has already paid any enterprise income tax overseas for the current-period income deemed as from dividend distribution, it may be entitled to a tax credit according to the relevant provisions of the CITL or tax agreement. ${ }^{10}$

If the Chinese resident enterprise shareholder is able to provide information to prove that its CFC meets any of the following conditions, the profits of the foreign enterprise that are not distributed or the deficit when the profits are distributed in a reduced amount may not be deemed as distributed dividends and not be included in the current-period income of the Chinese resident enterprise: (i) It is an enterprise formed in a non-low tax rate country (or region) as specified by the SAT; (ii) its incomes are mainly derived from its active business activities; or (iii) its total annual profits are less than 5 million RMB. ${ }^{11}$

In 2015, the SAT published the updated discussion draft of Circular 2 for the purpose of soliciting public opinions (State Administration of Taxation 2015c). Chapter 10 of the new draft has more detailed requirements on the CFCs from Article 114 through Article 125. However, this new draft has not been finalized yet by the end of June 2017.

\subsection{Responses to BEPS Action 4}

As far as the BEPS Action 4 is concerned, Article 46 of the CITL of 2007 offers the thin capitalization rule based on a fixed debt/equity ratio, by clarifying that the interest disbursement for any debt investments and equity investments, which an enterprise accepts from its affiliates, in excess of the prescribed criterion shall not be deducted in the calculation of the taxable amount of income. As the

\footnotetext{
Article 76, Circular 2 of 2009.

Article 77, Circular 2 of 2009.

Article 79, Circular 2 of 2009.

Article 82, Circular 2 of 2009

1 Article 84, Circular 2 of 2009.
} 
thin capitalization is closely connected with the interest deduction, Article 46 could be considered a general article on limiting base erosion involving interest deductions.

Pursuant to Article 46 of the CITL, Article 119 of CITLIR defines the term "debt investment" as the financing which an enterprise directly or indirectly obtains but has to repay the principal and pay interest or has to make compensation by any other means in the nature of interest payment. The debt investment obtained by an enterprise from any related party shall include: (i) Debt investment a related party provides through an unrelated third party; (ii) debt investment an unrelated third party provides which is guaranteed by a related party that assumes several and joint liabilities; (iii) any other debt investment indirectly obtained through any related party in the nature of obligation assumption. The term "equity-based investment" refers to the type of investment which an enterprise accepts for which it does not have to repay the principal and pay interest and the investor holds ownership over the net assets of the enterprise.

According to the authorization of Article 119 of CITLIR, Chapter IX of the Circular 2 of 2009 deals with the standards for identification of thin corporations in details from Article 85 through Article 91.

China has not issued further new detailed regulations to implement the recommended approach by the BEPS Action 4, based on a fixed ratio rule which limits an entity's net deductions for interest and payments economically equivalent to interest to a percentage of its earnings before interest, taxes, depreciation and amortization (EBITDA) by the end of 2016. However, generally speaking, the current regulations on thin capitalization function well in China.

The BEPS Action 4 requires the countries to undergo periodic OECD monitoring of interest deduction limitation rules according to a process to be determined. ${ }^{12}$ As China takes the BEPS package very seriously, China is expected to collaborate with the OECD on the monitoring process.

\subsection{Responses to BEPS Action 5}

According to the BEPS Action 5, it is a minimum standard for the countries to modify existing IP regimes to use nexus approach, and to use agreed grandfathering rules if modification will include transition rules. Additional four prescriptions of the BEPS Action 5 are, to adopt procedures to inform the OECD Harmful Tax Practices Forum if tax benefits are provided to specified IP assets, to adopt measures to monitor and gather data on companies benefitting from regimes to promote development in disadvantaged areas, to adopt procedures to spontaneously exchange statistical information with respect to specified IP-related rulings, and to adopt procedures to spontaneously exchange statistical information with respect to cases of insufficient IP-ruling related data gathering and exchange. ${ }^{13}$

Under Article 28 of CITL, the corporate income tax on important high-and-new-tech enterprises that are necessary to be supported by the state shall be levied at the reduced tax rate of $15 \%$. Such preferential regime on reduced rate for advanced technology enterprises in China is considered not harmful by the review process of the FHTP. ${ }^{14}$

\section{Responses to Mainly Treaty-Based Action Items (Items 6-7)}

\subsection{Responses to BEPS Action 6 on Treaty Shopping}

According to the BEPS Action 6, it is a minimum standard for the countries to include a principle purpose test (PPT) alone or combined with a limitation on benefits (LOB) provision, or a LOB provision combined with a specified anti-conduit rule. Additional three prescriptions of the BEPS Action 6 are, adopting anti-abuse rules to address tax avoidance strategies addressed throughout the Action Plans, including an express statement about a common intention to eliminate double taxation without

\footnotetext{
Action 4 Report, p. 13.

Action 5 Report, pp. 67-68.

Action 5 Report, p. 64.
} 
creating double non-taxation or treaty shopping opportunities and including a saving clause to preserve domestic taxation of residents subject to specified exceptions. ${ }^{15}$ Another relevant prescription from the BEPS Action 2 is to address hybrid mismatches in accordance with revisions to OECD Model Article. $^{16}$

Several bilateral tax treaties China signed in the process of developing the BEPS package have incorporated the LOB provision required by the Action 6. For instance, the Agreement between China and Chile for the Avoidance of Double Taxation and the Protocol thereto were formally signed in Santiago, Chile on 25 May 2015. The two parties have completed the required domestic legal procedures for the entry into force of the Agreement and the Protocol thereto. The Agreement and the Protocol thereto have come into force on 8 August 2016, and applies to income obtained on and after 1 January 2017. In addition to the LOB provision, this Agreement also introduced the PPT and the rule on identification of the existence of PE in triangular situations.

The similar approach was also taken in the Agreement between China and Russia for the Avoidance of Double Taxation and the Prevention of Fiscal Evasion with respect to Taxes on Income and the Protocol thereto and the Protocol Amending this Agreement formally signed in Moscow respectively on 13 October 2014 and 8 May 2015, and came into force on 9 April 2016.

Of course, no all the bilateral tax treaties have adopted the approach recommended by Action 6. However, as China has promised to implement the Action 6 as minimum standard, it is likely for China to comprehensively adopt the approach of the Action 6 by updating its bilateral treaties based on the new Multilateral Instrument required by the Action 15 in the near future.

To optimize the administration of non-resident taxpayers' enjoyment of the treatment under tax agreements, the SAT issued Bulletin on Issuing the Measures for the Administration of Non-Resident Taxpayers' Enjoyment of the Treatment under Tax Agreements (Bulletin 60 of 2015) on 27 August 2015.

Where non-resident taxpayers are eligible for the treatment under tax treaties, they may, when filing tax returns, or when withholding agents make withholding declaration, enjoy the treatment under agreements at their own discretion and be subject to the follow-up administration by tax authorities. ${ }^{17}$

Where, under the circumstance of withholding at source or designated withholding, non-resident taxpayers deem that they are eligible for the treatment under agreements, and need to enjoy the treatment under agreements, they shall take the initiative to put forward the request to withholding agents, and provide withholding agents with the relevant report forms and materials as prescribed in Article 7 of Bulletin 60. Where such documents are complete, and the information filled in the relevant report forms meets the requirements for enjoying the treatment under agreements, withholding agents shall withhold taxes in accordance with the provisions of agreements, and forward the relevant report forms and materials to the competent tax authorities while making withholding declaration. Where non-resident taxpayers fail to put forward the request for enjoying the treatment under agreements to withholding agents, or the materials provided for withholding agents or the information filled in the relevant report forms fail to meet the requirements for enjoying the treatment under agreements, withholding agents shall withhold taxes in accordance with the provisions of domestic tax laws. ${ }^{18}$

Although the tax authorities will give up their traditional power of prior approval on the treaty treatment or benefit, they will closely follow-up the non-resident taxpayers' enjoyment of the treaty benefit under agreements, and accurately execute tax agreements, so as to prevent the risks of treaty shopping. Therefore, such reform is both taxpayer-friendly and efficient.

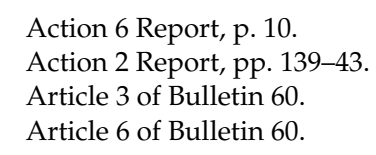


Where the competent tax authorities find in the process of the follow-up administration that the general rules on anti-tax avoidance in tax agreements or domestic tax laws shall apply, the general anti-tax avoidance investigation procedures may be initiated. ${ }^{19}$

A recent development of the restraint mechanism for the non-resident taxpayers is the credit evaluation and disclosure system. The competent tax authorities shall maintain credit archives for non-resident taxpayers' improper enjoyment of the treatment under agreements, and take corresponding follow-up administration measures. ${ }^{20}$

\subsection{Responses to BEPS Action 7 on Permanent Establishment (PE)}

The 2015 BEPS Report on Action 7 aims at preventing the artificial avoidance of PE status, and provides for changes to be made to Article 5 of the Model Tax Convention ("MTC"), so as to prevent artificial avoidance of $\mathrm{PE}$ status through use of commissionaires, fragmentation of activities and abuse of independent agent status. ${ }^{21}$ On 4 July 2016, the OECD published the Discussion Draft of Additional Guidance on the Attribution of Profits to PE.

China has shown great interest in tightening the regulation of the PE, and has directly endorsed the criteria for identifying the PE in the draft Report of Action 7 in the bilateral treaty with Chile signed on 25 May 2015, almost five months before the finalization of BEPS package in October 2015. However, it remains to observe whether similar approach will be followed in its subsequent treaties with other countries in the future.

Considering the fact that the SAT previously promised to support the PE definition in the BEPS package, it is expected that China will introduce this definition in most, if not all, of its bilateral treaties by multilateral automatic treaty modification based on the Multilateral Convention To Implement Tax Treaty Related Measures To Prevent Base Erosion And Profit Shifting of 2016 in the future. As some contracting countries are low tax jurisdictions, such as Luxembourg, the Netherlands, Ireland and Singapore, the modification of the bilateral treaties between China and those low tax jurisdictions will have huge impacts on the corporate structure and tax planning of the MNEs.

China has traditionally attributed the profit to PE based on the verification of the profit rate, instead of the AOA. Therefore, China has to decide whether and/or to what extent it is willing to implement the full AOA after the Additional Guidance on the Attribution of Profits to Permanent Establishments is finalized in the future. It is expected that the national information exchange and data analysis systems will help China identify the PE in the future.

Paragraph 1 of Article 5 (PE) of the tax agreements signed by China prescribes that: The term "PE" refers to a fixed place of business through which the business of an enterprise is wholly or partly carried out. Paragraph 4 of Article 5 prescribes that: The term "permanent establishment" shall not include the fixed business place established solely for of the enterprise itself to carry out any other activity of a preparatory or auxiliary nature.

To clarify the terms "business" and "preparatory or auxiliary" and other PE issues, the SAT released the Bulletin on the Relevant Issues about the Determination of Permanent Establishments in Tax Agreements (Bulletin No. 35 of 2006) on 14 March 2006. ${ }^{22}$ The term "business" refers to both business operations and common business operations conducted by NPOs. The following principles shall be followed when determining "preparatory or auxiliary" activities: (i) Whether the fixed base or place only provides services to its head office or whether it has any business relation with any other entity; (ii) whether the business nature of the fixed base or place is in line with that of its head office; and (iii) whether the business operations of the fixed base or place are an important part of those of its head office. If the fixed base or place not only provides services to its head office but also has

\footnotetext{
Article 22 of Bulletin 60.

Article 23 of Bulletin 60.

1 Action 7 Report, p. 9 et seq.

CLI.4.75564(EN).
} 
business relations with any other entity, or its business nature is in line with that of its head office and its business operations are an important part of those of its head office, the activities of such fixed base or place shall not be regarded as preparatory or auxiliary.

In the past years, China has paid great attention to the regulation of the service PE. The term "PE" in tax treaties encompasses that "the furnishing of services, including consultancy services, by an enterprise of a Contracting State through employees or other personnel in the other Contracting State, provided that such activities continue for the same project or a connected project for a period or periods aggregating more than six months within any twelve-month period."

The SAT clarified the determination of the PE of foreign enterprises providing services within china and the Attribution of profits to PE in its reply to Jiangsu Tax Authority on 19 July 2016. ${ }^{23}$ First, if a foreign enterprise without PE sends its employees to provide services, including consultancy services, for a connected project within China for more than six months within any twelve-month period, the PE shall be identified. Second, if a project lasts for several years and if the employees assigned by the foreign enterprise provide services more than six months, but other employees assigned by this foreign enterprise provide services not more than six months, the existence of PE shall be determined. This PE is based on all services which the foreign enterprise provides for the relevant project rather than the services provided in a certain period. Third, for a foreign enterprise which has a PE providing services for a certain project through its employees within China, the profits sourced from such project shall be taxed as the profits of the PE.

A frequently cited PE case was reported by China Tax News. In this case, a parent corporation incorporated in Singapore, $X$ corporation, established an equity joint venture of auto making in China, $Y$ corporation. $X$ corporation sent several groups of employees to provide technological instructions and post-sale services for the projects of $Y$ corporation in China. Beijing Tax Authority found that $X$ corporation had 51 PEs by sending employees providing services for more than 183 days between January 2012 and December 2015 in China. Y corporation disagreed by arguing that the employees of $\mathrm{X}$ corporation stayed less than 183 days, and therefore no PE would be constituted, and that the employees' income were paid outside the territory of China, therefore the employees of X corporation not obligated to pay individual income tax in China ${ }^{24}$.

The methodology for calculating the period of 183 days in aggregation has been reflected in many tax treaties signed by China and other contracting parties, and will play significant role in frustration of the strategies of abusive splitting-up of contracts. It is expected that China will be more actively in identifying the PE with the help of information sharing and regulatory collaboration between and among Chinese domestic government agencies and international counterparts.

The growth of E-Commerce and new business models in the digital economy poses serious challenges for applying the definition of PE to the world of e-commerce. China expressed its concern about the challenge and significance on the taxing the corporate income deriving from e-commerce in its comments on the UN Subcommittee on Base Erosion and Profit Shifting. "The development of the digital economy increases the online transactions. How to tax these transactions remains a difficulty for tax administrations. The action plans should consider how to tackle the challenges of digital economy on the existing tax systems and the revenue base (UN n.d.)".

While the OECD approach is to treat service income as business income under Article 7, the source State has no taxing rights unless the service income is attributed to a PE situated therein. The UN Model, however, grants greater taxing rights to the source State through the inclusion in Article 5 of a deemed service PE provision (Art. 5 (3) (b)), which is based on a time threshold (i.e., 183 days in any 12 -month period) concerning the service activities within a Contracting State. ${ }^{25}$

\footnotetext{
3 No. 694 [2006] of the State Administration of Taxation, 19 July 2006, CLI.4.78110(EN).

24 See http://www.ctaxnews.net.cn/html/2016-10/21/nw.D340100zgswb_20161021_1-05.htm.

25 See China Comments to BEPS, http://www.un.org/esa/ffd/tax/Beps/index.htm.
} 
As one of the basic features of the modern global economy is that a physical presence may no longer be required for the conduct of business, it is very common for a large range of cross-border services, such as design, engineering, financial consultancy, advertising to be performed from remote locations. In our opinion, it should be possible to devise a workable PE threshold that does not depend on physical presence but on a de minimis amount of sales of goods and services into a taxing jurisdiction. ${ }^{26}$

\section{Responses to Transfer Pricing Measures (Items 8-10 and 13)}

\subsection{General Requirements of BEPS Action Items 8-10 and 13}

BEPS Action Items 8-10 and 13 focus on areas of concern involving transfer pricing, and aims at bringing about rule changes involving the treatment of intangibles, of risks and capital, and of other high-risk transactions, as well as improving new "country-by-Country" $(\mathrm{CbC})$ reporting requirements. It is a minimum standard for the countries to adopt $\mathrm{CbC}$ reporting procedures for three-tiered reporting system of master file, local file, and $\mathrm{CbC}$ reports and to adopt international agreements and procedures to automatically exchange $\mathrm{CbC}$ reports. ${ }^{27}$

Additional Prescriptions include undergoing periodic OECD monitoring of $\mathrm{CBCR}$ implementation, ${ }^{28}$ revising allocation rules to attribute risks to related parties on the basis of control and financial capacity, ${ }^{29}$ revising allocation rules to prevent legal ownership as sole determinant of source of income attributed to intangibles, ${ }^{30}$ revising allocation rules to attribute value to companies that perform important functions, ${ }^{31}$ limiting non-controlling companies to risk-free return or less on financial transactions, ${ }^{32}$ limiting values attributed to group synergy to companies contributing to synergistic benefits ${ }^{33}$.

\subsection{The Legal Framework of Transfer Pricing and TP Documentation in China before the Release of BEPS Package in 2015}

Chapter 6 of the CITL, under the title "Special tax adjustments", provided the legal foundations of transfer pricing and TP documentation in China, including the authorization of tax authorities to adjust the tax, the arm length principle, cost contribution agreements (Article 41), advance pricing arrangements (APA, Article 42), annual report on the related transactions, adjustment methodology, CFCs (Article 45), thin capitalization (Article 46), and general anti-tax avoidance (GATA, Article 47), etc. Chapter 6 of the CITLIR further defined the terms used by Chapter 6 of the CITL in details.

For instance, Article 43 of CITL imposed the TP documentation requirements in China. When an enterprise files its annual corporate income tax returns with the tax authority, it shall enclose an annual report on the related party transactions. When the tax authority investigates into the related party transactions, the enterprise and its affiliates, as well as other enterprises relevant to the affiliated transactions under investigation, shall provide the pertinent documents.

Article 36 of the LATC also authorized Chinese tax authorities to make reasonable adjustments in case of the receipt or payment of charges or fees which are not priced at arm's length prices and results in a reduction of the taxable income.

Pursuant to the CITL, the CITLIR and the bilateral tax treaties on the avoidance of double taxation, the SAT released the Measures for the Implementation of Special Tax Adjustments

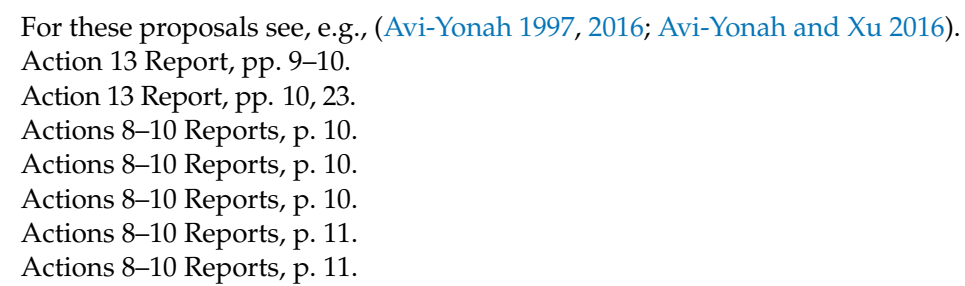


(for Trial Implementation) of 2009 (Circular 2), which represents the most comprehensive and significant regulation in addressing the transferring pricing and TP documentation in China before the release of the BEPS package in 2015. ${ }^{34}$

\subsection{Overview of the Transfer Pricing and $\mathrm{CbC}$ Reporting Changes in China}

To effectively implement the BEPS package in China and to comprehensively update the existing Circular 2, the SAT released a Discussion Draft of a Circular on Implementation Measures for Special Tax Adjustments ("Discussion Draft") in September 2015, ranging from Action 3 (CFC rules), Action 8-10 (Aligning TP outcomes with value creation) to Action 13 (TP documentation and $\mathrm{CbC}$ reporting) in details (State Administration of Taxation 2015c). Compared with 13 chapters and 118 articles in Circular 2, there are 16 chapters and 168 articles in the Discussion Draft of 2015.

Although the long-expected new single version of Circular 2 has not been finalized yet, a series of patches have been made to replace the substantial part of Circular 2. For instance, Article 69 of Circular 2 was replaced by the SAT Bulletin 45 of 16 June $2015 .{ }^{35}$ Chapters 2-3, Articles 74 and 89 of Circular 2 were replaced by the SAT Bulletin 42 on Matters concerning Improving the Administration of Affiliation Reporting and Contemporaneous Documentation of 29 June 2016. Chapter VI of the Circular 2 was replaced by the SAT Bulletin 64 on the Issues Concerning Improving the Administration of Advance Pricing Arrangements of 11 October 2016. Chapters 4-5, 10-11 of the Circular 2 were repealed by the SAT Bulletin 6 on Improving Administration of Special Tax Investigation and Adjustment and Mutual Agreement Procedures of 17 March 2017 (State Administration of Taxation 2017a).

Following the release of the aforesaid Bulletins, the majority of innovative institutional arrangements proposed in the 2015 Discussion Draft have been produced as s series of separate items. It is likely that the remaining parts of the Discussion Draft will also be released as piecemeal documents, rather than as a single comprehensive regulation. As a result, the existing valid parts left in Circular 2 are only Chapter 7 (cost sharing agreements) except Articles 69 and 74 annulled by Bulletin 42, Chapter 8 (CFC), Chapter 9 (thin capitalization) except Articles 89 annulled by Bulletin 42, and Chapter 10 (general anti-avoidance).

Bulletin 45 of 2015, Bulletins 42 and 64 of 2016, and Bulletin 6 of 2017 have not only substantially updated the transfer pricing specific clauses of Circular 2, but also basically reflected the final results of the BEPS package, especially Actions 8-10, and Action 13. As China has totally endorsed the underlying standards on transfer pricing, BEPS project enhances has substantially promoted the convergence of transfer pricing standards between China and other countries.

\subsection{TP Documentation Requirements of Bulletin 42 of 2016}

The $\mathrm{CbC}$ report and contemporaneous documentation are one of the four minimum standards of the BEPS package. To implement the BEPS Action 13, the SAT released Bulletin 42 of 2016, which fundamentally updated the previous requirement for contemporaneous documentation under Chapter 2, Chapter 3, Article 74 an Article 89 of Circular 2, and the requirement for annual reporting of related party transactions under Circular No. $114^{36}$.

As the first step of the SAT to localize OECD/G20 BEPS Project recommendations into domestic legislation, Bulletin 42 introduced the three-tiered framework of comprehensive related-party transactions reporting and improved the existing contemporaneous documentation, based on Circular 2. Bulletin 42 established ambitious TP compliance requirements at two levels: (i) RPT Forms, including three forms/tables of $\mathrm{CbC}$ report; and (ii) three-tiered contemporaneous documentation, including master file, local file and special file. As the $\mathrm{CbC}$ report is incorporated in the RPT Forms of

\footnotetext{
34 No. 2 [2009] of the SAT (Guoshuifa [2009] No. 2).

35 No. 45 [2015], SAT (State Administration of Taxation 2015d).

36 Document No. 114 [2008], SAT.
} 
2016, China has developed four-tiered standardized approach (master file, local file, special file and $\mathrm{CbC}$ report).

Any resident enterprise subject to tax levied on auditing accounting books and non-resident enterprise with establishments or offices in China subject to corporate income tax levied on an actual basis, should report its related-party transactions in a fiscal year by filling the annual report forms on related-party transactions (RPT Forms), along with the annual corporate income tax return, by May 31 of every fiscal year. ${ }^{37}$

Bulletin 42 recognizes five types of related-party transactions: (i) Transfer of the right to use or ownership of tangible assets, including commodities, products, buildings and structures, means of transportation, machinery equipment, tools and instruments; (ii) transfer of financial assets, including accounts receivables, notes receivables, other receivables, equity investment, debt investment, and the assets formed by derivative financial instruments; (iii) transfer of the right to use or ownership of intangible assets, including patent right, know-how, trade secrets, trademark right, brands, list of clients, sales channels, franchised rights, government licensing, and copyright; (iv) accommodation of funds, including all types of long-and short-term loans (including capital pool of the group), guarantee expenses, all types of prepayments with accrued interest, delayed receipts and payments; (v) trading of services, including market investigation, marketing planning, agency, design, consulting, administration, technical services, contracted R \& D, maintenance, legal services, financial management, auditing, recruitment, training and centralized procurement. ${ }^{38}$

Under Article 11 of Circular 2 and Circular 114, there were nine old RPT Forms. To enhance the global transparency of the BEPS picture of the MNE group, Bulletin 42 increased the lengths of RPT Forms to 22 items, including: Reporting entity information form (compulsory); annual summary form on related party transactions (compulsory); related party relationship form (compulsory); transfers of ownership in tangible assets form; transfers of ownership in intangible assets form; transfers of rights to use tangible assets form; transfers of rights to use intangible assets form; financial assets transaction form; financing form; related party services form; equity investment form; cost contribution agreement form; outbound payment form; overseas related party information form; financial analysis form of annual affiliated transactions between enterprises (unconsolidated); financial analysis form of annual affiliated transactions between enterprises (consolidated); form on the global allocation of income, taxes and business activities; list of entities within the multinational group; and additional information. The last three forms on the $\mathrm{CbC}$ report should be prepared in both Chinese and English.

Given the fact that not every table/form in the 22 RPT Forms is mandatory for the taxpayer to file, and given the different thresholds for the taxpayers to prepare certain forms, this author speculate that, although some MNEs need to file all the RPT forms, most taxpayers will be only required to file not more than nine forms as before the release of Bulletin 42. The SAT also expressed the same idea (State Administration of Taxation 2016).

As envisaged by the BEPS Action 13 Report, the $\mathrm{CbC}$ report will provide annually the amount of revenue, profit before income tax, income tax paid and accrued, number of employees, stated capital, retained earnings, tangible assets, business activities of each entity of the MNE group in each tax jurisdiction. Following the model legislation of the BEPS Action 13 Report, Bulletin 42 made it mandatory for large MNEs to file the CbC report in three forms/tables, as part of RPT Forms of 2016, for the purpose of disclosing the global allocation of the income, taxes paid and economic activity among countries.

In the past decades, Chinese tax authorities have complained about the difficulties in acquiring the full global picture of MNEs' value-creating activities and profit allocations. With the help of the $\mathrm{CbC}$ Report, tax authorities will obtain a preliminary understanding of the allocation of a MNE's

37 Article 1 of Bulletin 42, Article 54 of the CITL.

38 Article 4 of Bulletin 42 . 
profits around the globe, the distribution of the entities/jurisdictions engaging specific activities along an MNE's value chain, and the relevant tax positions for each of the tax jurisdictions. Of course, the authentic, accurate and complete $\mathrm{CbC}$ report will also help the MNEs to demonstrate their compliance with the arm's length principle on their transfer pricing activities. Therefore, $\mathrm{CbC}$ report will benefit both the tax authorities and the taxpayers.

The primary reporting entity is the ultimate holding company of the MNE group with annual consolidated group revenue in the immediately preceding fiscal year of not less than 5.5 billion RMB, roughly equivalent to the threshold of Euro 750 million as specified under the BEPS Action 13 Report. The ultimate parent entity is able to consolidate the financial statements of all constituent entities under its umbrella, while its own financial statements cannot be consolidated by any other enterprises. The secondary reporting entity is the constituent entity nominated or designated by the MNE group to file the $\mathrm{CbC}$ Report. ${ }^{39}$

Chinese tax authorities may also request a taxpayer under special tax investigation to provide a $\mathrm{CbC}$ report in any of the following circumstances: (i) The MNE group has not provided a $\mathrm{CbC}$ report to any country; (ii) although the MNE group has provided a $\mathrm{CbC}$ report to another country, China has not established the information exchange mechanism on the $\mathrm{CbC}$ report with that country; or, (iii) despite the fact that the MNE group has provided the $\mathrm{CbC}$ report to another country with such mechanism with China, China has not successfully obtained the $\mathrm{CbC}$ report. ${ }^{40}$

Bulletin 42 requires qualified taxpayers to prepare the $\mathrm{CbC}$ report by completing three specified forms/tables under the BEPS Action 13 Report, including: (i) Overview of allocation of income, taxes and business activities by tax jurisdiction; (ii) list of all the constituent entities of the MNE group included in each aggregation per tax jurisdiction; and (iii) additional information.

As recommended by the BEPS Action 13 Report, the first $\mathrm{CbC}$ Reports would be filed by 31 December 2017. For MNEs with a fiscal year ending on a date other than 31 December, the first CbC Reports would be required to be filed later in 2018, twelve months after the close of the relevant MNE fiscal year, and would report on the MNE group's first fiscal year beginning after 1 January 2016. Thus, inter-government exchange mechanism is expected to be ready for the exchange of the first $\mathrm{CbC}$ Reports.

In response to the three-tier structure for transfer pricing documentation as set out in BEPS Action 13, Bulletin 42 restructured the contemporaneous documentation into a three-tier structure, including master file, local file and special file. The qualified taxpayers should prepare and file contemporary documentation on related party transactions in the fiscal year at the request of the tax authority. ${ }^{41}$ As each file has its own filing thresholds, it is possible for one taxpayers to file two or three of the contemporaneous documents.

\subsection{Bulletin 6 of 2017 on the Special Tax Investigations and Adjustments}

To further streamline and improve the transparency and predictability of transfer pricing investigations undertaken by Chinese tax authorities, SAT released its long-awaited Bulletin on Special Tax Investigations, Adjustments and Mutual Agreement Procedures ("Bulletin 6") on 28 March 2017, as another step in converting the BEPS Actions 8-10 Reports into domestic regulations on transfer pricing. Bulletin 6 was effective from 1 May 2017, and replaced Chapters 4, 5, 11 and 12 of Circular 2, Circular 188, Circular 363, Bulletin 54 and Bulletin 16.

Bulletin 6 not only reflects the outcome of the BEPS Actions 8-10 Reports, but also consolidates previous regulations and existing practices on transfer pricing. It is expected that the introduction of Bulletin 6 will greatly improve the predictability, reliability and transparency of transfer pricing

39 Article 5 of Bulletin 42.

40 Article 8 of Bulletin 42.

41 Article 10 of Bulletin 42. 
investigations by clarifying the focus points and the rationale of Chinese tax authorities, standardize the transfer pricing investigation practices, and indirectly force the corporations to take initiatives on voluntary and honest self-adjustments.

Embedded in treaties and appears as Article 9(1) of the OECD and UN Model Tax Conventions, interpreted by OECD's Transfer Pricing Guidelines, the arm's length principle (ALP) is re-emphasized by the BEPS package. To help tax authorities and taxpayers evaluate transfer prices between associated enterprises, and to prevent double taxation, China also uses the ALP as the cornerstone of transfer pricing rules. Article 37 of Bulletin 6 authorized tax authorities to "make adjustments to the full amount of payments made to overseas related parties that have performed no function, assumed no risk or carried out no substantive activities, which are not in compliance with the arm's length principle".

Article 4 of Bulletin 6 listed 9 categories of target corporations with the risk features to be investigated by tax authorities: (i) Enterprises with significant amount or substantially multiple types of related-party transactions; (ii) enterprises with longtime losses, low profitability or fluctuating profitability; (iii) enterprises with profit levels lower than average levels of the same industry; (iv) enterprises whose profit levels do not match their functions performed and risks assumed, or whose shared benefits do not match their allocated costs (CCA); (v) enterprises that transact with related parties in low tax jurisdictions (tax havens); (vi) enterprises that fail to file their related-party transaction reporting forms or to prepare contemporaneous documentation; (vii) enterprises whose related-party debt-to-equity ratio exceeds the standard ratio (thin capitalization); (viii) enterprises incorporated in a jurisdiction where the effective tax rate is lower than $12.5 \%$, controlled by Chinese tax resident companies, or by Chinese tax resident companies and Chinese nationals, having either failed to distribute profits or reduced the distribution of profits without reasonable business needs (CFC); (ix) enterprises who engage in tax planning schemes or tax arrangements that lack reasonable business purposes (general anti-avoidance, GAA).

Under Article 4 of Bulletin 6, both residents and non-residents shall be subject to investigation. This is likely to happen in the cases involving CFC or GAA issues. Tax authorities may deal with non-residents either directly or through a resident related party. According to the interpretation of SAT, the legal basis for the investigation of the foreign tax residents is the CIT (State Administration of Taxation 2017b). Such a legal basis should be Article 43 of the CITL, which said, "When the tax organ investigates into the affiliated transactions, the enterprise and its affiliates, as well as other enterprises relating to the affiliated transactions under investigation, shall provide the pertinent materials according to the relevant provisions". Article 114 (2) of the CITLR further referred the term "other enterprises relating to the related transaction under investigation" to those enterprises that are similar to the enterprise under investigation in the contents and pattern of production and business management.

The special tax adjustment is generally not applicable to wholly domestic related party transactions. Based on the approach of Article 30 of Circular 2, Article 38 of Bulletin 6 provides that, "as a general principle, no special tax adjustment shall be made with respect to the transaction between domestic affiliates whose actual tax burdens are the same, provided the transaction has not directly or indirectly decreased the overall tax revenue of China".

The process of special tax investigation would be generally launched in case of the failure of appropriate self-adjustment of the taxpayers. Therefore, Bulletin 6 encourages the taxpayers to take initiative to adjust its transfer pricing on its own. Tax authorities may also remind the taxpayers of any taxation risk in question, based on verification of the RPT reporting, administration of the contemporaneous documentation and monitoring of corporate profit level. When taxpayers choose to self-adjust, they should file the newly introduced "Special Tax Adjustments Self-Payment Form" ${ }^{4}$

Tax authorities shall initiate special tax investigations in cases where taxpayers request tax authorities to confirm the principles and methods of the transfer pricing. Despite any self-adjustments

42 Article 3 of Bulletin 6. 
by taxpayers, tax authorities may use their discretion to initiate a special tax audit process if they deem the self adjustment is insufficient.

Based on the presumption that there would be profits attributable to LSAs, Bulletin 6 requires Chinese tax authorities to analyze LSAs such as the cost savings and market premiums, and select appropriate and reasonable transfer pricing methods to determine LSAs' contribution to profits, where the comparable corporation and investigated corporation operate in different economic conditions. ${ }^{43}$ Chinese tax authorities have long emphasized the significance of LSAs, and endeavored to ensure Chinese taxpayers are compensated for LSAs that allow the MNE group to earn higher profits. The significance of LSAs' impact on transfer pricing analysis has been expressly recognized by Bulletin 42 and Bulletin 64. For instance, the LSAs requirement is reflected in the local file documentation as the factors affecting transfer pricing and profits in the value chain under Bulletin 42.

Consistent with the OECD Guidelines, Article 111 of the CITLIR recognized the comparable uncontrolled price method (CUP), the resale price method (RPM), the cost-plus method (CPM), the transactional net margin method (TNMM), the profit split method (PSM), and other methods in compliance with the arm's-length principle. Article 16 of Bulletin 6 continues to authorize the tax authorities to choose one of the above-mentioned reasonable transfer pricing methods, based on the comparable analysis, to analyze the related party transactions. The detailed guidance of Bulletin 6 on the methods generally reflected the positions of the OECD Guidelines.

Article 22 of Bulletin 6 introduced three frequently used asset valuation methods, including cost, market and income, to support transfer pricing analysis of the transactions of either individual pieces of corporate assets, including intangible assets, or entire corporate assets as a whole.

This Article also introduced a broad language "Other methods in compliance with the arm's length principle" as to include any other reasonable methods that comply with the arm's length principle, and can appropriately reflect the principle that profits should be taxed where economic activity takes place and where value is created. The broad wording of "other methods" will offer necessary discretion and flexibility for tax authorities to employ any reasonable methods available to reflect the principle that profits should be taxed where economic activity takes place and where value is created, for the purpose of fair and reasonable special tax adjustment.

The controversial term value contribution allocation method (VCAM) or value chain apportionment method introduced in Article 35 of Discussion Draft of 2015, which was considered akin to formulary apportionment by some, has been dropped from Bulletin 6 . Some consultants interpreted this major change as a response to criticisms made by commentators on the Consultation Draft (EY n.d.). This author argues that the silence of Bulletin 6 on VCAM does not imply that VCAM will never be used by Chinese tax authorities. Quite contrary, the term "Other methods in compliance with the arm's length principle" is broad enough to empower Chinese tax authorities to directly or indirectly use the VCAM or similar terms when necessary.

A further good example is the GVCAM advocated by the Jiangsu Provincial Office of SAT. Based on the practice of transfer pricing investigation, APA and consensus with some MNEs, Jiangsu Office urged the MNEs to change their mindset and try a new transfer pricing method based on the analysis of global value chain. GVCAM can be divided into three steps: (i) Collecting sufficient information including the Group's master file, $\mathrm{CbC}$ report, commercial databases, internal financial data, etc. The subsidiaries should strengthen intra-group communication and to promote full understanding of the substance of relevant information; (ii) analyzing the operation and profit of the group value chain, clarify the functions and relevant undertakers on the value chain, and identify the core elements in value creation, such as intangibles, fixed assets, personnel and market; (iii) allocating the total profit on the value chain to different function bearers according to a set of core indicators (such as assets, sales, expenses, costs, etc.) to ensure that the allocation match the functions performed

43 Article 27 of Bulletin 6. 
and the risks assumed by these parties on the value chain (Jiangsu Provincial Office, Sat 2016). As Jiangsu is one of the economic power houses with active operations of MNEs in China, it is likely that other Chinese tax authorities would follow Jiangsu's pioneer model. The reason is very simple.

\subsection{Transfer Pricing of Intangible Property Transactions}

Different from the traditional unilateral approach to the payment of royalties paid by Chinese enterprises to the oversea affiliates, Bulletin 6 introduced the bilateral approach to the payment of royalties between Chinese enterprises and their affiliates, including the payment received by Chinese corporations from their oversea affiliates. As the new rules on transfer pricing of intangible property transactions covers both transferors and transferees of intangibles, Chinese tax authorities will give enough attention to the BEPS risks associated with intangibles transactions between the members of China-based MNE groups. Therefore, it is essential for China-based MNE groups to ensure the arm's length nature of the royalties received by Chinese taxpayers from their oversea affiliates as licensees of intangibles. It is expected that there will be serious discussions on the BEPS risk associated with the royalty received by Chinese taxpayers from their offshore affiliates. Of course, Chinese tax authorities will not weaken their priority focus on the traditional BEPS risks arising from the payment of the royalties from Chinese corporations to their oversea affiliates.

In addition to duplicating the five functions (DEMPE) outlined by the BEPS Actions 8-10 Reports and OECD Transfer Pricing Guidelines, Bulletin 6 identifies "Promotion" of intangibles as another key function for the purpose of "DEMPEP" analysis. As Chinese tax authorities will conduct six-function (DEMPEP) analysis of the intangibles transactions under the new rules, the value contribution by and through marketing and promoting activities undertaken by Chinese companies will be appropriately rewarded. This innovation further reinforced Chinese traditional emphasis on the huge value of marketing and promotion efforts in attracting Chinese consumers to buy international brands at the price of generous premiums.

The DEMPEP analysis depends on different facts and circumstances, including business models of the MNE group and intangibles natures of the related party transactions. However, Bulletin 6 is silent on further quantification and weighting of the performance of various contribution in considering the arm's length adjustment of income related to intangible property between and among various members of the MNE group. The necessary discretion should be controlled by rule of law especially the due process of law, so as to strike a good balance between sophisticated taxpayers and tax authorities in the process of arm's length analysis of transfer pricing of intangibles transactions.

To warrant the predictability of tax audit and adjustment, the SAT would be well advised to develop detailed guidance based on Chinese specific circumstances and the BEPS Actions 8-10 Reports in the future. Neither ignorance of the significant functions of design and control, nor ignorance of the significant functions of exploitation and promotion is rationale and convincing without regard to the facts and circumstances in specific individual cases in question.

Under Bulletin 6, an entity that merely owns the legal ownership of intangible assets, but has not contributed towards the value creation of the intangible assets, should not be entitled to any benefit arising from the exploitation of such intangible assets. ${ }^{44}$ Such position reflected the recommendations of the BEPS Actions 8-10 Reports, which indicates that, "For intangibles, the guidance clarifies that legal ownership alone does not necessarily generate a right to all (or indeed any) of the return that is generated by the exploitation of the intangible"; "Legal ownership of intangibles by an associated enterprise alone does not determine entitlement to returns from the exploitation of intangibles". ${ }^{45}$

44 First paragraph, Article 30 (2) of Bulletin 6.

45 Actions 8-10 Reports, pp. 10, 64. 
Under Bulletin 6, an entity that has merely funded intangible development activities but has not performed any DEMPEP functions or assumed any risks in the creation and exploitation of intangible assets, should only be entitled to a reasonable financing return. ${ }^{46}$

Under Bulletin 6, tax authorities may conduct special tax adjustment on the royalties received or paid as a result of intangibles licensing transactions, in case of the failure of timely adjustment by the taxpayer on one of the following situations: (i) The value of intangible assets have changed fundamentally; (ii) an adjustment mechanism on royalty for comparable transactions between unrelated parties would have been in place, pursuant to usual and normal business practices; (iii) the functions performed, risks assumed and assets used by the enterprise and its related parties have changed during the course of the exploitation of intangible assets; (iv) the enterprise and its affiliates have not been appropriately compensated for the ongoing DEMPEP of intangibles. ${ }^{47}$ These rules are generally consistent with recommendations under the BEPS Actions 8-10 Reports, although discussions there are much more detailed.

Tax authorities are expected to pay particular attention to whether the value of the licensed intangibles has declined since the royalty was initially established, whether price adjustment clauses are commonly found in uncontrolled comparable transactions, whether the related parties have changed their functions as well as assets and risks have changed, and whether the transferee or the licensee has performed further additional DEMPEP functions for which it has not been reasonably and fairly compensated.

The core spotlight of Article Bulletin 6 is the recognition of the principle of benefit commensurate with the royalty rate. Bulletin 6 declares that the royalty paid or received for the transaction of intangibles should match the economic benefits generated by the intangibles for the enterprise or its affiliates. If the royalty does not match the economic benefit derived to the enterprise or its affiliates, and thus result in a reduction in the taxable gross income or taxable income of the enterprise or its related party, tax authorities may initiate special tax adjustment on such royalty. Assuming the licensed intangibles have generated no economic benefit, and assuming the transactions are not arm's length, tax authorities may make adjustments up to the full amount of the royalties paid. Assuming an enterprise pays a royalty to a related party that merely has the ownership of the intangibles, and assuming the royalties are not arm's length, tax authorities may make special adjustments up to the full amount of the royalty. ${ }^{48}$

These rules have reinforced the substance principle reflected in the BEPS package and the recommendations of the BEPS Actions 8-10 Reports, including "legal ownership of intangibles by an associated enterprise alone does not determine entitlement to returns from the exploitation of intangibles, and associated enterprises performing important value-creating functions related to the development, maintenance, enhancement, protection and exploitation of the intangibles can expect appropriate remuneration" ${ }^{49}$ The substance principle requires the magnitude of royalty specified in the contracts to be commensurate with the economic benefit in substance, and thus ensures arm's length pricing.

\subsection{Transfer Pricing of Intra-Group Service Transactions}

Articles 34-36 of Bulletin 6 are designed to determine the nature and level of the arm's length in related party service transactions, based on Article 4 of Bulletin 16 and existing enforcement practice, and inspired by the internationally accepted and OECD sanctioned "benefits test".

As indicated by the BEPS Actions 8-10 Reports, there are two issues in the analysis of transfer pricing for intra-group services. One issue is whether intra-group services have in fact been provided.

\footnotetext{
46 Second paragraph, Article 30 (2) of Bulletin 6.

47 Article 31 of Bulletin 6.

48 Article 32 of Bulletin 6.

49 Actions 8-10 Reports, p. 64.
} 
The other issue is what the intra-group charge for such services for tax purposes should be in accordance with the arm's length principle. ${ }^{50}$

Following the same line of thinking, Article 34 of Bulletin 6 introduces two interrelated principles for the transfer pricing of intra-group service transactions to follow: The benefit principle and the ALP. First, the related-party services should be beneficial to the service recipient. Second, the service fee paid or received should be arm's-length. In case of the failure to satisfy the two interrelated requirements, a special tax adjustment shall be made.

To determine whether intra-group services have been rendered, the second paragraph of Article 34 of Bulletin 6 introduces benefits test recommended by the BEPS Actions 8-10 Reports. The arm's length related party service transactions should be beneficial service transactions that are priced according to business practices and fair prices for transactions conducted between unrelated parties in the same or comparable circumstances. The term "beneficial service" is defined as the service activity, which is able to deliver direct or indirect economic benefit to the recipient, and which an independent enterprise would have been willing to pay for or would have performed the activity in-house for itself, in the same or comparable circumstances.

The first paragraph of Article 34 of Bulletin 6 authorizes tax authorities to make a special tax adjustment by disallowing the deduction of the service fee, where an enterprise pays the service fee to its related parties for services that are not beneficial.

Although Bulletin 6 has not provided any detailed documentation requirements on the intra-group service transactions, it will be very helpful for the recipient and the provider of services to prepare and maintain genuine and reliable documents, including the books and records, to support the existence of beneficial services and the compliance of the ALP. It is irresponsible for the taxpayers and the tax consultants to wait for the SAT guidance before preparing the documents. The rationale is that the burden of proof on the compliance of the ALP is on the shoulder of the parties to intra-group service transactions, instead of the tax authorities.

Article 35 of Bulletin 6 listed 6 categories of non-beneficial intra-group service: (i) Duplicative services (services that has already been procured or carried out by the enterprise itself); (ii) shareholder activities (services that is carried out to exercise control, management and supervision of the enterprise with a view to protecting the investment interests of a direct or indirect investor); (iii) services that benefit solely from being part of the group (service not specifically carried out for the recipients, although the enterprise has obtained an incidental benefit by belonging to a particular group); (iv) services that have already been compensated in another related party transaction; (v) services that are irrelevant to the functions performed or risks assumed by service recipients, or do not meet the business needs of the service recipients; (vi) any other services that cannot bring direct or indirect economic benefit to the service recipient, or that an independent enterprise would have been unwilling to pay for or would not have performed the activity in-house for itself.

Based on the BEPS Actions 8-10 Reports, Article 36 of Bulletin 6 introduced the direct and indirect charging methods for related party services, except for the elective, simplified approach introduced by the BEPS Actions 8-10 Reports for low value-adding intra-group services of Chapter VII of the Transfer Pricing Guidelines. The elective, simplified approach specifies a wide category of common intra-group services which command a very limited profit mark-up on costs, applies a consistent allocation key for all recipients for those intra-group services, and provides greater transparency through specific reporting requirements including documentation showing the determination of the specific cost pool. ${ }^{51}$ The reason is that SAT has long considered all intra-group service transactions are highly risky.

Article 36 of Bulletin 6 requires the reasonable pricing methods to be selected based on the consideration of the concrete content and features, the functions, risks, cost and expense undertaken by

50 Actions 8-10 Reports, p. 144.

51 Actions 8-10 Reports, p. 14. 
the service provider, the benefits and market circumstances of the recipient, the financial situation of the transactions parties, and the pricing level of comparable transactions. Where the direct "reasonable cost" is unavailable, the indirect "apportioned cost" shall be identified based on the match between the benefit enjoyed by the recipient and the outcome of the apportionment. Compared with the Discussion Draft, Article 36 of Bulletin 6 deleted the language "plus an arm's length mark-up" on calculating a service fee.

The impact of Article 36 of Bulletin 6 is that the ALP will be actively applied to the intra-group service transactions, and the MNE groups have to reflect and readjust their existing unreasonable transfer pricing policies correspondingly. For example, where an overseas affiliate has outsourced all of the service that it used to provide to a corporate taxpayer in China, the outsourcing affiliate may not charge the Chinese taxpayer for the serve provided by external unrelated parties any more.

\section{Conclusions}

As indicated above, China has actively participated in both developing and implementing the BEPS project. China's tax base has been seriously eroded by aggressive international tax planning that has the effect of artificially shifting profits to locations where they are subject to non-taxation or substantially reduced taxation.

In the first three earlier decades since the late 1970s, China had received more inbound foreign direct investments including advanced technologies and intangibles than the outbound investment of Chinese investors. However, as China started to implement the "Going-out" strategy in the 21st century, in particular the initiative of "one belt and one road" (OBOR), more and more China-based corporations are increasingly active in outbound investment and intangibles export oversea. In response to the new scenario of increasingly accelerated globalization of China-based MNE groups, China has to take a very holistic approach to deal with the BEPS challenges from different perspectives, including domestic action items (items 2-5), treaty-based action items (items 6-7) and transfer pricing measures (items $8-10$ and 13).

In the post-BEPS era, China is expected to implement the BEPS project in a more consistent and coherent way, and will take whatever measures necessary to guarantee the successful implementation of the BEPS package in collaboration with the global community. That is why the SAT has quickly translated many minimum standards and recommendations of BESP project into domestic regulations.

China has been one of most active countries in endorsing its international obligation created under the BEPS project. For instance, on 7 June 2017, China joined other 67 jurisdictions in Paris for the official signing ceremony for a new multilateral tax instrument (MLI). ${ }^{52}$ China signed the MLI not only by itself, but also on behalf of the Hong Kong Special Administrative Region of the People's Republic of China. China and other 47 Signatories agreed to modify their 47 bilateral treaties among the existing 102 bilateral treaties China entered with 102 contracting countries (OECD 2017c).

In China, the bilateral treaties prevail over the domestic law. For instance, Article 91 of the LATC of 2015 states that, "If the provisions of the relevant tax treaties or agreements concluded between the People's Republic of China and foreign countries are in conflict with the provisions of this Law, the relevant matters shall be handled in accordance with the treaties or agreements". Article 58 of the CITL declares that, "Where any provision in a tax treaty concluded between Chinese government and a foreign government is different from the provisions in the CITL, the provision in the treaty shall prevail". Despite the controversial debate of the legal effect of the tax treaties, the SAT tends to argue that the tax treaties are not only legally binding on the governments of the contracting

52 (OECD 2017a); see also (OECD 2017b) (listing the 68 jurisdictions, plus eight other countries that intend to sign soon). The Signatories include the major OECD and EU members (except for the US), China and India, as well as many important treaty shopping jurisdictions (e.g., the Netherlands and Mauritius) and tax havens (e.g., Singapore and Hong Kong). 
parties, but are also directly applicable to the taxpayers (State Administration of Taxation n.d.). Therefore, we believe that China will implement the BEPS project in a serious manner.

Of course, the implementation of BEPS project might invite new uncertainty both for taxpayers and for administrators during the short transitional period between the articulation and the implementation of the action plans. It is also possible for some taxpayers to design new tax planning strategies of regulatory arbitrage in the transitional period, in order to avoid the application of both traditional norms and new norms. The Chinese government could address the new challenges by modernizing its tax governance with the help of big data and big analysis of its own domestic information platform and the international information sharing system.

Author Contributions: Reuven S. Avi-Yonah proposed the topic of this paper, discussed its outline with Haiyan $\mathrm{Xu}$ and wrote the introduction. Meanwhile, Haiyan Xu wrote the remainder of the paper. Afterwards, Reuven S. Avi-Yonah reviewed the entire article and made further revisions.

Conflicts of Interest: The authors declare no conflict of interest.

\section{References}

Ault, Hugh J. 2013. Some Reflections on the OECD and the Sources of International Tax Principles. Tax Notes International 70: 1195, Working Paper of the Max Planck Institute for Tax Law and Public Finance No. 2013-03. Available online: http:/ / ssrn.com/abstract=2287834 or http:/ / dx.doi.org/10.2139/ssrn.2287834 (accessed on 20 January 2018). [CrossRef]

Ault, Hugh J., Wolfgang Schoen, and Stephen E. Shay. 2014. Base Erosion and Profit Shifting: A Roadmap for Reform. Bulletin for International Taxation 68: 275, Boston College Law School Legal Studies Research Paper No. 324. Available online: http:/ / ssrn.com/abstract=2459646 (accessed on 20 January 2018).

Avi-Yonah, Reuven S. 1997. International Taxation of Electronic Commerce. Tax Law Review 52: 507-23.

Avi-Yonah, Reuven S. 2016. Three Steps Forward, One Step Back? Reflections on "Google Taxes" and the Destination-Based Corporate Tax. Nordic Tax Journal 2: 1. [CrossRef]

Avi-Yonah, Reuven S., and Haiyan Xu. 2016. Evaluating BEPS: A Reconsideration of the Benefits Principle and Proposal for UN Oversight. Harvard Business Law Review 6: 185-238. [CrossRef]

Brauner, Yariv. 2014. What the BEPS? Available online: http:/ / ssrn.com/abstract=2408034 or http:/ / dx.doi.org/ 10.2139/ssrn.2408034 (accessed on 20 January 2018).

China Daily. 2017. Top 10 Countries Projected to Attract Most FDI. Available online: http:/ /www.chinadaily.com. cn/bizchina/2017top10/2017-05/03/content_29175979.htm (accessed on 20 January 2018).

Committee of Experts on International. 2014. Responses to Questionnaire for Developing Countries from the UN Subcommittee on Base Erosion and Profit Shifting. Available online: http://www.un.org/esa/ffd/tax/ tenthsession/CRP12_BEPS.pdf (accessed on 20 January 2018).

Dharmapala, Dhammika. 2014a. What Do We Know about Base Erosion and Profit Shifting? A Review of the Empirical Literature. Illinois Public Law Research Paper No. 14-23; University of Chicago Coase-Sandor Institute for Law \& Economics Research Paper No. 702. Available online: http:/ / ssrn.com/abstract=2373549 or http:/ / dx.doi.org/10.2139/ssrn.2373549 (accessed on 20 January 2018).

Dharmapala, Dhammika. 2014b. Base Erosion and Profit Shifting: A Simple Conceptual Framework. University of Chicago Coase-Sandor Institute for Law \& Economics Research Paper No. 703. Available online: http:/ / ssrn.com/abstract=2497770 (accessed on 20 January 2018).

Economic and Social Council. 2014. Appointment of Three New Members to the Committee of Experts on International Cooperation in Tax Matters. Available online: http://www.un.org/ga/search/view_doc.asp? symbol=E/2014/9/Add.18\&Lang=E (accessed on 20 January 2018).

EY. n.d. SAT's Newly Released Bulletin 6 Strengthens MAP Procedures in Advance of Peer Reviews and Enhances Alignment of China's Transfer Pricing Rules with OECD Standards. Available online: http:/ / www.ey.com/Publication/vwLUAssets/ey-china-tp-alert-sat-newly-released-bulletin-6/\$FILE/eychina-tp-alert-sat-newly-released-bulletin-6.pdf (accessed on 20 January 2018).

Financing for Development. n.d. Committee of Experts on International Cooperation in Tax Matters. Available online: http:/ / www.un.org/esa/ffd/tax/index.htm (accessed on 20 January 2018). 
G20. 2016. G20 Leaders' Communique Hangzhou Summit. Available online: https:/ /www.g20.org/Content/ DE/_Anlagen/G7_G20/2016-09-04-g20-kommunique-en.pdf?_blob=publicationFile\&v=6 (accessed on 20 January 2018).

G20 Information Centre. 2013. G20 Leaders' Declaration. Available online: http:/ /www.g20.utoronto.ca/2013/ 2013-0906-declaration.html (accessed on 20 January 2018).

G20 Information Centre. 2014. G20 Leaders' Communiqué. Available online: http:/ /www.g20.utoronto.ca/2014/ 2014-1116-communique.html (accessed on 20 January 2018).

G20 Information Centre. 2015. G20 Leaders' Communiqué. Available online: http://www.g20.utoronto.ca/2015/ 151116-communique.html (accessed on 20 January 2018).

Grinberg, Itai. 2015. Breaking BEPS: The New International Tax Diplomacy. Available online: http:/ / ssrn.com/ abstract=2652894 or http:/ / dx.doi.org/10.2139/ssrn.2652894 (accessed on 20 January 2018).

Jiangsu Provincial Office, Sat. 2016. Homepage of Jiangsu Provincial Office of SAT. Available online: http: / / www.jsgs.gov.cn/art/2016/8/9/art_55_256279.html (accessed on 20 January 2018).

Ministry of Foreign Affairs of the People's Republic of China. 2013. Jointly safeguard and develop an open world economy-Statement on World Economic Situation at the First Phase of the Group of Twenty Leaders' Summit (by Xi Jinping). Available online: http:/ /www.fmprc.gov.cn/web/gjhdq_676201/gjhdqzz_681964/ ershiguojituan_682134/zyjh_682144/t1073568.shtml (accessed on 20 January 2018).

Ministry of Foreign Affairs of the People's Republic of China. 2016. Xi Jinping's Keynote Speech at the Opening Ceremony of the Group of Twenty Commerce and Industry Summit. Available online: http:/ /www.fmprc. gov.cn/web/gjhdq_676201/gjhdqzz_681964/ershiguojituan_682134/zyjh_682144/t1394306.shtml (accessed on 20 January 2018).

OECD. 2015. Centre for Tax Policy and Administration, OECD presents outputs of OECD. Paper presented at G20 BEPS Project for discussion at G20 Finance Ministers Meeting, Lima, Peru, October 5.

OECD. 2016a. China and the OECD A Mutually Beneficial Partnership. Available online: http://www.oecd.org/ china/active-with-china.pdf (accessed on 20 January 2018).

OECD. 2016b. BEPS ACTION 2 BRANCH MISMATCH STRUCTURES. Available online: http:/ /www.oecd.org/ tax/beps/Discussion-draft-Action-2-Branch-mismatch-structures.pdf (accessed on 20 January 2018).

OECD. 2017a. Ground-Breaking Multilateral BEPS Convention Signed at OECD Will Close Loopholes in Thousands of Tax Treaties Worldwide. Available online: http://www.oecd.org/tax/ground-breakingmultilateral-beps-convention-will-close-tax-treaty-loopholes.htm (accessed on 20 January 2018).

OECD. 2017b. Signatories and Parties to the Multilateral Convention to Implement Tax Treaty Related Measures to Prevent Base Erosion and Profit Shifting. Available online: http:/ /www.oecd.org/tax/treaties/beps-mlisignatories-and-parties.pdf (accessed on 20 January 2018).

OECD. 2017c. Signing Ceremony-Multilateral Convention to Implement Tax Treaty Related Mesures to Prevent Base Erosion and Profit Shifting. Available online: https://oecdtv.webtv-solution.com/3827/or/signing ceremony_multilateral_convention_to_implement_tax_treaty_related_mesures_to_prevent_base_erosion_ and_profit_shifting.html (accessed on 20 January 2018).

OECD. n.d. OECD: Members and Partners. Available online: http:/ /www.oecd.org/about/membersandpartners / (accessed on 20 January 2018).

Rosenzweig, Adam H. 2014. Building a Framework for a Post-BEPS World. Tax Notes International 74. Available online: http:/ / ssrn.com/abstract=2463259 (accessed on 20 January 2018).

Shaviro, Daniel. The Crossroads Versus the Seesaw: Getting a 'Fix' on Recent International Tax Policy Developments. NYU School of Law, Public Law Research Paper No. 15-20; NYU Law and Economics Research Paper No. 11-15. Available online: http:/ / dx.doi.org/10.2139/ssrn.2605144 or http:/ /ssrn.com/ abstract $=2605144$ (accessed on 20 January 2018).

State Administration of Taxation. 2013. Announcement on Enterprise Income Tax Treatment for Mixed Enterprise Investment Business. Available online: http:/ / www.chinatax.gov.cn/n810341/n810755/c1145382/content.html (accessed on 20 January 2018).

State Administration of Taxation. 2015a. State Administration of Taxation Issues OECD/G20 Base Erosion and Profit Shifting Project 2015 Final Report (Chinese version). Available online: http:/ / www.chinatax.gov.cn/ n810219/n810724/c1836574/content.html (accessed on 20 January 2018). 
State Administration of Taxation. 2015b. In-Depth Study of BEPS Action Plans, Do Well in China's Participation in the Development of Multilateral Tax Rules. Available online: http:/ /www.chinatax.gov.cn/n810219/ n810729/c1674429/content.html (accessed on 20 January 2018).

State Administration of Taxation. 2015c. Special Tax Adjustment Implementation. Available online: http:/ / hd. chinatax.gov.cn/hudong/noticedetail.do?noticeid=577376 (accessed on 20 January 2018).

State Administration of Taxation. 2015d. Notice on Regulating the Management of Cost-Sharing Agreements. Available online: http:/ / www.chinatax.gov.cn/n810341/n810765/n1465977/n1466032/c1813135/content.html (accessed on 20 January 2018).

State Administration of Taxation. 2016. Interpretation on "Notice of the State Administration of Taxation on Perfecting the Relevant Issues of Related-Party Information and Data Management During the Same Period". Available online: http:/ /www.chinatax.gov.cn/n810341/n810760/c2208475/content.html (accessed on 20 January 2018).

State Administration of Taxation. 2017a. Announcement on the Measures for the Administration of Procedures for Adjustment and Mutual Consultation of Special Tax Investigations. Available online: http:/ / www.chinatax. gov.cn/n810341/n810755/c2538695/content.html (accessed on 20 January 2018).

State Administration of Taxation. 2017b. Answers to Relevant Questions on Issuing the Measures for the Administration of Procedures for Adjustment and Consultation of Special Tax Investigations. Available online: http:/ /www. chinatax.gov.cn/n810341/n810760/c2538658/content.html (accessed on 20 January 2018).

State Administration of Taxation. n.d.; The Legal Status of the Tax Treaties and its Relationship with the Domestic Law. Available online: http:/ /www.chinatax.gov.cn/n810219/n810744/n1671176/n1705734/c1705580/ content.html (accessed on 20 January 2018).

UN. n.d. China's Reply to the BEPS Questionnaire of the UN Subcommittee. Available online: http:/ / www.un. org/esa/ffd/tax/Beps/CommentsChina_BEPS.pdf (accessed on 20 January 2018).

Vann, Richard J. 2014. Policy Forum: The Policy Underpinnings of the BEPS Project-Preserving the International Corporate Income Tax? Canadian Tax Journal 62: 433-41, Sydney Law School Research Paper No. 14/77. Available online: http:/ / ssrn.com/abstract=2483619 (accessed on 20 January 2018).

(C) 2018 by the authors. Licensee MDPI, Basel, Switzerland. This article is an open access article distributed under the terms and conditions of the Creative Commons Attribution (CC BY) license (http:/ / creativecommons.org/licenses/by/4.0/). 